\title{
Consumption Tax, Nontraded Goods and Welfare
}

\author{
Wataru Johdo \\ Faculty of Economics, Tezukayama University, Nara, Japan \\ Email: johdo@tezukayama-u.ac.jp
}

Received July 3, 2013; revised August 3, 2013; accepted August 13, 2013

Copyright (C) 2013 Wataru Johdo. This is an open access article distributed under the Creative Commons Attribution License, which permits unrestricted use, distribution, and reproduction in any medium, provided the original work is properly cited.

\begin{abstract}
This paper studies the welfare effects of a consumption tax rise based on the two-sector small open economy model of Obstfeld and Rogoff (1995) and Lane (1997). The main findings of our analysis are that 1) in the case of free trade, the consumption tax rise has no effect on welfare, 2) when there is the nontraded goods sector, the consumption tax rise has a negative effect on welfare, and 3) the larger the share of nontraded goods in consumption is, the larger the negative welfare effect of consumption tax will be.
\end{abstract}

Keywords: Consumption Tax; Nontraded Goods; Trade Openness; Small Open Economy; Welfare

\section{Introduction}

In the new open economy macroeconomics literature pioneered by Obstfeld and Rogoff [1], the relationship between monetary expansions and aggregate economic activity has been studied extensively at the theoretical level. ${ }^{1}$ This literature has focused on how the macroeconomic activity and welfare of multiple countries are influenced by unanticipated monetary shocks in one country under monopolistic distortions and price rigidities. The benchmark model of Obstfeld and Rogoff [1] shows that a domestic monetary expansion raises consumption in both countries by lowering the world interest rate, which results in an increase in world consumption demand, and thereby improves foreign and domestic welfare. At the same time, in the appendix, Obstfeld and Rogoff [1] also sketch a small open economy model that incorporates a nontraded goods sector and show the possibility of exchange rate overshooting. Then, Lane [5] extends the small open economy model in Obstfeld and Rogoff [1] to include government behavior and shows how variation in trade openness affects the welfare effects of expansionary monetary policy shocks. Furthermore, Cavallari [6] and Lee and Chinn [7] also take the two-sector small open economy model of Obstfeld and Rogoff [1] (or Lane [5]) and study how the current account and exchange rate are influenced by monetary policy shocks. Johdo [8] also generalizes the two-sector small open economy model of Lane [5] to include habit

\footnotetext{
${ }^{1}$ For surveys of the new open economy macroeconomics models, see
} Lane [2], Sarno [3] and Lane and Ganelli [4]. formation, and examine how the strength of habit formation affects the response of welfare to monetary policy shocks.

However, no studies have attempted to examine the welfare effects of an increase in a consumption tax by using the two-sector small open economy model. The purpose of this paper is to contribute theoretically to the new open economy macroeconomics literature by generalizing the small open economy model of Obstfeld and Rogoff [1] and Lane [5] to include a consumption tax rate and examining the question of how the degree of trade openness (or the share of nontraded goods in consumption) affects the response of welfare to an increase in the consumption tax rate.

The main findings of our analysis are that 1) in the case of free trade, the consumption tax rise has no effect on welfare, 2) when there is the nontraded goods sector, the consumption tax rise has a negative effect on welfare, and 3) the larger the share of nontraded goods in consumption is, the larger the negative welfare effect of consumption tax will be.

The remainder of this paper is structured as follows. In Section 2, we outline the features of the model. In Section 3 , we present the symmetric equilibrium with flexible nominal prices. In Section 4, we present a log-linearized version of this model. In Section 5, we analyze the welfare effect of a permanent consumption tax rise and examine how the degree of trade openness affects the responses of welfare to the consumption tax shock. Section 6 gives the conclusion. 


\section{A Two-Sector Small Open Economy Model}

Following Obstfeld and Rogoff [1] and Lane [5], we consider a small open economy with two sectors, a traded goods sector and a nontraded goods sector, with nominal price rigidities. The traded goods sector is characterized by a single homogeneous endowment, and the price of traded goods is determined in perfectly competitive world markets. Meanwhile, the nontraded goods sector is a monopolistically competitive market with differentiated goods. In this model, a unit mass of agents is characterized as both consumers and producers, where each agent produces a unit of nontraded differentiated goods. The agents have perfect foresight, derive their utility from consuming a homogeneous good and a group of differentiated goods and from holding real money balances, and incur the cost of expending labor (or production) effort.

The intertemporal objective of a typical agent at time 0 is to maximize the following lifetime utility:

$$
\begin{aligned}
U_{0}= & \sum_{t=0}^{\infty} \beta^{t}\left\{\delta \log C_{T t}+(1-\delta) \log C_{N t}\right. \\
& \left.+\chi \log \frac{M_{t}}{P_{t}}-\frac{\eta}{2} y_{N t}(i)^{2}\right\},
\end{aligned}
$$

where $\beta \in(0,1)$ is a constant subjective discount factor, $y_{N t}(i)$ is the agent's output of nontraded goods in period $t, \delta \in(0,1)$ is the share of the consumption of traded goods, $C_{T t}$ is consumption of the traded good, and $C_{N t}$ is composite nontraded goods consumption, defined as:

$$
C_{N t}=\left(\int_{0}^{1} C_{N t}(i)^{(\theta-1) / \theta} \mathrm{d} i\right)^{\theta /(\theta-1)},
$$

where $\theta(>1)$ is the elasticity of substitution between any two differentiated goods and $C_{N t}(i)$ is the consumption of nontraded good $i$. The second term in (1) represents real money balances $\left(M_{t} / P_{t}\right)$, where $M_{t}$ denotes nominal money balances held at the beginning of period $t+1$, and $P_{t}$ is the consumption price index, which is defined as:

$$
P_{t}=\frac{\left(1+\tau_{t}\right) P_{T t}^{\delta} P_{N t}^{1-\delta}}{\delta^{\delta}(1-\delta)^{1-\delta}},
$$

where $\tau_{t}$ is the consumption tax rate and $P_{N t}$ is the price of nontraded goods and is defined as:

$$
P_{N t}=\left(\int_{0}^{1} P_{N t}(i)^{1-\theta} \mathrm{d} i\right)^{1 /(1-\theta)},
$$

and $P_{T t}$ is the domestic currency price of traded goods. Because there are no trade costs, the law of one price holds for traded goods; i.e., $P_{T t}=E_{t} P_{T t}{ }^{*}$, where $E_{t}$ is the nominal exchange rate and $P_{T t}{ }^{*}$ is the exogenously de- termined world price. A typical agent faces the following budget constraint:

$$
\begin{aligned}
P_{T t} B_{t+1}+M_{t} & =P_{T t}(1+r) B_{t}+M_{t-1}+P_{N t}(i) y_{N t}(i) \\
& +P_{T t} y_{T}-\left(1+\tau_{t}\right)\left(P_{T t} C_{T t}+P_{N t} C_{N t}\right)+T_{t},
\end{aligned}
$$

where $B_{t+1}$ denotes real bonds denominated in traded goods in period $t+1, r$ denotes the world real interest rate in traded goods on bonds that applies between periods $t-1$ and $t$, and $T_{t}$ denotes lump-sum transfers from the government. In the government sector, we assume that government spending is zero. Hence, the government budget constraint is $\tau_{t}\left(P_{T t} C_{T t}+P_{N t} C_{N t}\right)+M_{t}-M_{t-1}=T_{t}$. In addition, in this model, each agent is endowed with a constant amount of the traded good in each period. Therefore, as shown in (5), we can delete the subscript $t$ from $y_{T t}$, i.e., $y_{T t}=y_{T}, \forall t$.

At the first stage, agents maximize the consumption index (2) subject to a given level of expenditure on nontraded goods $P_{N t} C_{N t}=\int_{0}^{1} P_{N t}(i) C_{N t}(i) \mathrm{d} i$ by optimally allocating differentiated nontraded goods. This static problem yields the following demand function for $\operatorname{good} i$ :

$$
y_{N t}(i)=\left(\frac{P_{N t}(i)}{P_{N t}}\right)^{-\theta} C_{N A t},
$$

where $C_{N A t}$ is aggregate consumption. At the second stage, agents maximize (1) subject to (5). For simplicity, we assume $\beta(1+r)=1$. Then, the first-order conditions for this problem can be written as:

$$
\begin{gathered}
C_{T t+1}=C_{T t}, \\
C_{N t}=\left(\frac{1-\delta}{\delta}\right)\left(\frac{P_{T t}}{P_{N t}}\right) C_{T t}, \\
\left(\frac{1}{1+\tau_{t}}\right)\left(\frac{\delta}{C_{T t}}\right)=\chi\left(\frac{M_{t}}{P_{t}}\right)^{-1}\left(\frac{P_{T t}}{P_{t}}\right) \\
+\beta\left(\frac{P_{T t}}{P_{T t+1}}\right)\left(\frac{1}{1+\tau_{t}}\right)\left(\frac{\delta}{C_{T t+1}}\right), \\
\left.y_{N t}(i)^{(\theta+1) / \theta}\right]\left(\frac{(\theta-1)(1-\delta)}{\theta \eta}\right]\left(\frac{1}{1+\tau_{t}}\right)\left(\frac{1}{C_{N t}}\right)\left(C_{N A t}\right)^{1 / \theta},
\end{gathered}
$$

and the terminal condition is

$$
\lim _{T=\infty}(1 / 1+r)^{T}\left[B_{t+T+1}+\left(M_{t+T} / P_{t+T}\right)\right]=0 .
$$

\section{Steady-State Flexible Price Equilibrium}

Henceforth, we assume that initial net foreign assets are zero $\left(B_{0}=0\right)$. In the steady state, all exogenous variables are constant. Substituting (8) into (10) and considering 
the symmetric equilibrium $C_{N}=y_{N}=C_{N A}$, we obtain:

$$
C_{N}=y_{N}=\left[\frac{(\theta-1)(1-\delta)}{\theta \eta}\right]^{1 / 2}\left(\frac{1}{1+\tau}\right)^{1 / 2} .
$$

Equation (11) shows that all agents produce the same output of nontraded goods. Meanwhile, from (7) and a fixed endowment of traded goods output, the consumption of traded goods remains constant in each period; i.e., $C_{T t}=y_{T}, \forall t$. This implies that the current account is always balanced.

\section{A Log-Linearized Analysis with Nominal Rigidities}

To examine the effects of an unanticipated permanent consumption tax rise, we solve a log-linear approximation of the system around the initial, zero-shock steady state. Following Obstfeld and Rogoff [1] and Lane [5], we assume nominal price rigidities under which the price of nontraded goods in period $t$ is predetermined at time $t$ -1 . In addition, the price of nontraded goods is assumed to be fully adjusted after one period. For any variable $X_{t}$, we use $\hat{X}_{t}\left(\hat{X}_{t+1}\right)$ to denote the short-run (long-run) percentage deviation from the initial steady-state value. The short-run percentage deviation is proportional to the degree of the nominal price rigidity under which the output of nontraded goods is determined by demand. In the long run, the price of nontraded goods adjusts perfectly to the new steady-state value to be consistent with the optimal conditions (10).

First, in the short run, as the price of nontraded goods is sticky, we obtain $\hat{P}_{N t}=0$. In addition, as the consumption of traded goods remains constant in each period, we obtain $\hat{C}_{T t}=\hat{C}_{T t+1}=0$. By log-linearizing Equations (8) and (9), and considering $\hat{P}_{N t}=0$ and $\hat{C}_{T t}=0$, respectively, we obtain:

$$
\begin{aligned}
\hat{P}_{T t} & =\hat{C}_{N t}, \\
-\hat{P}_{T t} & =\frac{\beta}{1-\beta}\left(\hat{P}_{T t}-\hat{P}_{T t+1}\right)+\left(\frac{1}{1+\tau}\right) \mathrm{d} \tau .
\end{aligned}
$$

Equation (12) shows that the consumption of nontraded goods is affected positively by the price of traded goods in the short run. Equation (13) shows that the price of traded goods is affected by the consumption tax rise. With $\hat{P}_{N t}=0$, the short-run response in the consumption price index is

$$
\hat{P}_{t}=\left(\frac{1}{1+\tau}\right) \mathrm{d} \tau+\delta \hat{P}_{T t} .
$$

In the long run, the economy reaches a steady state. Therefore, for the price of traded goods, we obtain $\hat{P}_{T t+1}=\hat{P}_{T t+2}$. Substituting $\hat{P}_{T t+1}=\hat{P}_{T t+2}$ into the long-run case of (13), we obtain:

$$
\hat{P}_{T t+1}=-\left(\frac{1}{1+\tau}\right) \mathrm{d} \tau<0 .
$$

In addition, from the consumption price index, we obtain

$$
\hat{P}_{t+1}=\left(\frac{1}{1+\tau}\right) \mathrm{d} \tau+\delta \hat{P}_{T t+1}+(1-\delta) \hat{P}_{N t+1} .
$$

Furthermore, from (8), we obtain

$$
\hat{P}_{T t+1}=\hat{P}_{N t+1}+\hat{C}_{N t+1} .
$$

Substituting (17) into (16), we obtain

$$
\hat{P}_{t+1}=\left(\frac{1}{1+\tau}\right) \mathrm{d} \tau+\hat{P}_{T t+1}-(1-\delta) \hat{C}_{N t+1} .
$$

From (11), we obtain

$$
\hat{C}_{N t+1}=\hat{y}_{N t+1}=-\frac{1}{2}\left(\frac{1}{1+\tau}\right) \mathrm{d} \tau<0 .
$$

Substituting (15) and (19) into (18), we obtain

$$
\hat{P}_{t+1}=\frac{1}{2}\left(\frac{1-\delta}{1+\tau}\right) \mathrm{d} \tau>0 .
$$

Equation (20) shows that the consumption tax rise always increases the consumption price index in the long-run. Meanwhile, in the small open economy model, because the world price of traded goods is determined exogenously and $P_{T t}=E_{t} P_{T}{ }^{*}$ always holds, we obtain $\hat{P}_{T t}=\hat{E}_{t}$ in the short run. This implies that the price of traded goods reacts proportionately to the exchange rate. By substituting $\hat{P}_{T t}=\hat{E}_{t}$ into (13), the short-run response of the exchange rate to a consumption tax rise is given by:

$$
\hat{E}_{t}=-\left(\frac{1}{1+\tau}\right) \mathrm{d} \tau<0 .
$$

Equation (21) shows that a rise in the consumption tax rate appreciates the exchange rate. Therefore, from $\hat{P}_{T t}=\hat{E}_{t},(14)$ and (21), the consumption tax rise always increases the consumption price index in the short-run, $\hat{P}_{t}=[(1-\delta) /(1+\tau)] \mathrm{d} \tau>0$. Finally, from (12) and (21), we obtain:

$$
\hat{C}_{N t}=-\left(\frac{1}{1+\tau}\right) \mathrm{d} \tau<0 .
$$

Equation (22) shows that the consumption tax rise decreases the consumption of nontraded goods in the short run. In addition, from (6) and $P_{N}(i) / P_{N}=1$, we obtain $\hat{y}_{N t}=\hat{C}_{N t}$. Therefore, by linking this to (22), we obtain:

$$
\hat{y}_{N t}=\hat{C}_{N t}=-\left(\frac{1}{1+\tau}\right) \mathrm{d} \tau<0 .
$$

Equation (23) shows that the consumption tax rise also decreases the output of nontraded goods in the short run. 


\section{Welfare Analysis}

Our interest here lies in exploring the welfare effects of a consumption tax rise. Recalling that $\hat{C}_{T t}=\hat{C}_{T t+1}=0$, we can rewrite Equation (1) as:

$$
\Delta U=\Delta U_{R}+\Delta U_{M},
$$

where

$$
\begin{aligned}
\Delta U_{R}= & (1-\delta) \hat{C}_{N t}-\eta y_{N 0}^{2} \hat{y}_{N t} \\
& +\frac{\beta}{1-\beta}\left[(1-\delta) \hat{C}_{N t+1}-\eta y_{N 0}^{2} \hat{y}_{N t+1}\right], \\
\Delta U_{M}= & \chi\left(\hat{M}_{t}-\hat{P}_{t}\right)+\chi\left(\frac{\beta}{1-\beta}\right)\left(\hat{M}_{t+1}-\hat{P}_{t+1}\right),
\end{aligned}
$$

where $y_{N 0}$ denotes the initial steady-state output of nontraded goods. The short-run and long-run results for nontraded consumption, output and price index can be used to derive the impact of a consumption tax rise on welfare. By substituting these results into (24), we obtain:

$$
\begin{aligned}
\Delta U & =-\left(\frac{1-\delta}{1+\tau}\right)\left(1+\frac{\beta}{2(1-\beta)}\right) \\
& \times\left[\left(1-\frac{\theta-1}{\theta(1+\tau)}\right)+\chi\right] \mathrm{d} \tau<0 .
\end{aligned}
$$

The first term of the right hand side in square brackets of Equation (25) reflects the net welfare effect, composed of the welfare loss from a decrease in the consumption of nontraded goods and the welfare gain from a decrease in the production effort of nontraded goods. From $\delta<1$ and $\theta>1$, we find that the first term of Equation (25) is always negative. The second term is the welfare loss from a decrease in the real balances through $\hat{P}_{t}>0$ and $\hat{P}_{t+1}>0$. Therefore, the impact of a consumption tax rise on welfare is always negative.

The intuitive explanation is as follows. The welfare effect is determined by two mechanisms. On the one hand, an unanticipated permanent consumption tax rise requires an instantaneous decrease in the price of traded goods to restore the traded goods market equilibrium for a given constant endowment of tradable output. With fixed nontraded goods prices, the decrease in the price of traded goods in turn raises the relative price of nontraded goods and thereby decreases the consumption of nontraded goods. The importance of this negative nontradable consumption effect depends positively on the share of nontraded goods in consumption, $(1-\delta)$. On the other hand, the consumption tax rise also increases the price index and thereby decreases real balances. Here, recall from $\hat{P}_{T t}=\hat{E}_{t},(14)$ and (21) that the impact of a consumption tax rise on the price index depends positively on the share of nontraded goods in consumption, $(1-\delta)$, from $\hat{P}_{t}=[(1-\delta) /(1+\tau)] \mathrm{d} \tau>0$. Therefore, the scale of this negative real balance effect depends positively on $(1-\delta)$. Thus, for reasons mentioned above, the larger the share of nontraded goods in consumption, the larger the negative welfare effect of consumption tax.

Here, remember that the parameter $\delta(0<\delta<1)$ measures the degree of trade openness, where $\delta$ approaches one as the degree of trade openness increases and approaches zero when trade is extremely costly. Therefore, Equation (25) also shows that the larger the size of trade cost, the larger the negative welfare effect of consumption tax.

Incidentally, in the extreme case of free trade $(\delta=1)$, the impact of a consumption tax rise on welfare is:

$$
\Delta U_{\delta=1}=0 \text {. }
$$

Thus, under free trade, the consumption tax rise has no effect on welfare. Intuitive explanation of this result is as follows. First, the negative nontradable consumption effect disappears when $\delta=1$ as shown in the above. Second, recall that the consumption tax rise has two opposing effects on the consumption price index. On the one hand, a rise in the consumption tax increases the price index directly from (3). On the other hand, the consumption tax rise decreases the price index through an appreciation in the nominal exchange rate (see (21)). Therefore, there are two conflicting price index effects of a consumption tax rise. However, from $\hat{P}_{T t}=\hat{E}_{t}$, (14) and (21), when $\delta=1$, these two changes in the price index offset each other, and hence, the negative real balance effect also disappears. Thus, under free trade, the consumption tax rise has no effect on welfare.

\section{Conclusion}

We have used the two-sector small open economy model of Obstfeld and Rogoff [1] and Lane [5] to consider the response of welfare to a consumption tax rise. The main findings of our analysis are that 1) in the case of free trade, the consumption tax rise has no effect on welfare, 2) when there is the nontraded goods sector, the consumption tax rise has a negative effect on welfare, and 3) the larger the share of nontraded goods in consumption is, the larger the negative welfare effect of consumption tax will be. In particular, the latter results indicate the following policy implication: when trade is costly, the consumption tax rate must be decreased from a welfare point of view. Further, the actual data suggest that the second result in the above is consistent with the impacts of a consumption tax rise in Japan and the UK. Indeed, in Japan, the consumption tax rate was raised from $3 \%$ to $5 \%$ in 1997 , while the real GDP growth rate was $2.6 \%$ in 1996 but it fell to $1.6 \%$ in 1997 (IMF, 2013 [9]). In addition, recently, in the UK, the consumption tax rate was raised from $17.5 \%$ to $20 \%$ in 2011 , while the real GDP growth rate was $1.8 \%$ in 2010 but it fell to $0.9 \%$ in 2011 
(IMF, 2013, [9]). Therefore, the main result of this paper is supported with the actual data, because, in both Japan and UK, the real GDP growth rates fall after the consumption tax rise.

\section{Acknowledgements}

The author would like to thank an anonymous referee for valuable comments and suggestions. The author is also grateful to have received financial support from Tezukayama University.

\section{REFERENCES}

[1] M. Obstfeld and K. Rogoff, "Exchange Rate Dynamics Redux," Journal of Political Economy, Vol. 103, No. 3, 1995, pp. 624-660. http://dx.doi.org/10.1086/261997

[2] P. R. Lane, "The New Open Economy Macroeconomics: A Survey," Journal of International Economics, Vol. 54, No. 2, 2001, pp. 235-266. http://dx.doi.org/10.1016/S0022-1996(00)00073-8

[3] L. Sarno, "Towards a New Paradigm in Open Economy Modelling: Where Do We Stand?” Federal Reserve Bank of St. Louis Review, Vol. 83, No. 3, 2001, pp. 21-36.

[4] P. R. Lane and G. Ganelli, "Dynamic General Equilibrium Analysis: The Open Economy Dimension," In: A. Altug, J. S. Chaddha and C. Nolan, Eds., Dynamic Macroeconomic Analysis, Cambridge University Press, Cambridge, 2003, pp. 308-334.

[5] P. R. Lane, "Inflation in Open Economies," Journal of International Economics, Vol. 42, No. 3-4, 1997, pp. 327347. http://dx.doi.org/10.1016/S0022-1996(96)01442-0

[6] L. Cavallari, "Current Account and Exchange Rate Dynamics," Economic Notes, Vol. 30, No. 1, 2001, pp. 27-51. http://dx.doi.org/10.1111/1468-0300.00046

[7] J. Lee and M. D. Chinn, "Current Account and Real Exchange Rate Dynamics in the G7 Countries," Journal of International Money and Finance, Vol. 25, No. 2, 2006, pp. 257-274.

http://dx.doi.org/10.1016/i.jimonfin.2005.11.002

[8] W. Johdo, "Does Monetary Expansion Improve Welfare under Habit Formation?" Economics Bulletin, Vol. 33, No. 3, 2013, pp. 1959-1968.

[9] International Monetary Fund, "World Economic Outlook Database," International Monetary Fund, Washington DC, 2013. 